Vol. 13, $n^{\circ} 1 \mid 2009$

Varia

\title{
Crime and criminal justice history in Germany. A report on recent trends
}

Herbert Reinke

\section{(2) OpenEdition \\ Journals}

Electronic version

URL: https://journals.openedition.org/chs/698

DOI: $10.4000 /$ chs. 698

ISSN: 1663-4837

Publisher

Librairie Droz

Printed version

Date of publication: 1 March 2009

Number of pages: 117-137

ISBN: 978-2-600-01295-9

ISSN: 1422-0857

\section{Electronic reference}

Herbert Reinke, "Crime and criminal justice history in Germany. A report on recent trends", Crime, Histoire \& Sociétés / Crime, History \& Societies [Online], Vol. 13, n | 2009, Online since 01 March 2012, connection on 22 March 2022. URL: http://journals.openedition.org/chs/698 ; DOI: https://doi.org/ $10.4000 /$ chs. 698 


\title{
Crime and criminal justice history in Germany. A report on recent trends
}

\author{
Herbert Reinke'
}

\section{INTRODUCTION}

Tn Germany, modern crime and criminal justice history had a late start ${ }^{2}$. In the 1970s and the early 1980s, when crime and criminal justice history had already become a significant feature of historical writing in Western Europe and in Northern America, very few pioneers among German historians had ventured into the area. Three pioneers stand out: Dirk Blasius, Carsten Küther and Alf Lüdtke ${ }^{3}$.

By the time that the statement was made about the 'late start' of the history of German crime and criminal justice, however, the beginnings of a significant growth - quantitatively and qualitatively - was observable. Since then, specific fields of crime and criminal justice history in Germany have grown significantly. Moreover some, such as the history of the police, have grown to such an extent that this survey can only cover trends in the broadest sense; it cannot claim to provide a comprehensive bibliographical coverage. There is now a German book series on the history of crime and criminal justice ${ }^{4}$; beyond that, the number of monographs and edited volumes covering German nineteenth- and twentieth-century police has grown significantly since the beginning of the 1980s. The specificities of German history during the twentieth century (the Nazi dictatorship 1933-1945, the communist regime in Eastern Germany 1945-1989/1990) and the role of the respective police institutions during these periods, have done much to ensure that the history of police holds a special position within the history of crime and criminal justice in German.

For almost a quarter of a century a study of the history of crime, first published in 1951, was the only relevant publication in field. This book, written by Gustav Radbruch and Heinrich Gwinner, was novel because the authors explicitly understood their book as an attempt to write a cultural history of crime and not a history of criminal law ${ }^{5}$. It was also noteworthy because of the prominence of one of the

1 Herbert Reinke, criminologist / historian at the Center for Research on Antisemitism, Technical University Berlin / Germany, a number of publications (German / English / French) on the history of the police, on crime pattens and on cultural meanings of crime, current research interest: «Underworlds. Crime and Control in Berlin, 1930-1950» (herbert.reinke@tu-berlin.de).

2 Lüdtke, Reinke (1996, p. 109).

3 Blasius (1976, 1978); Küther (1976, 1983); Lüdtke (1982).

$4 \quad$ Konflikte und Kultur. Historische Perspektiven, Konstanz, Universitätsverlag, 16 volumes published since 1999.

5 Radbruch, Gwinner (1951/1991). 
authors: Gustav Radbruch was one of the leading jurists of the Weimar Republic and, as a member of the Social Democratic Party, he served for some years during that period as the minister of justice in the national government. Probably due to this fact, the book was reprinted in 1991. Until the mid1970s Radbruch's and Gwinner's book remained the only major text in the field. German historians had focused their interest elsewhere, and German law historians concentrated primarily on the history of civil law. There were, of course, some dissertations submitted in law faculties that dealt with German criminal justice history, but in general the history of law meant civil law. Significantly, the history of law chairs within German universities were, almost exclusively, concerned with the domain of civil law.

\section{GERMAN CRIME AND CRIMINAL JUSTICE HISTORIES}

\section{A. Crime and Criminal Justice History as Social History}

In the mid-1970s Küther's study of organized banditry from the eighteenth to the early twentieth centuries and Blasius' research into bourgeois society and criminality in early nineteenth-century Prussia, marked the beginnings of a modern crime and criminal justice history in Germany. Both authors, and above all Blasius, attempted a synthesis by covering an extensive range of issues, such as criminality, criminal law, the police, the courts, and the prisons. They both conceptualized their research by using concepts developed and employed by English and American historians. This meant primarily that their work was guided by conflict theories of crime and criminal justice and by the concepts of social criminality and social banditry, developed and elaborated by Eric Hobsbawm, Edward Thompson and others. In addition they deployed theoretical approaches deriving from criminology and sociology, especially those subsumed under the heading 'labeling theories' and these served as a conceptual background for explaining patterns of crime and criminal justice in the past. Küther understood banditry as the expression of a direct, primitive and archaic form of political and social protest, through which members of a rural vagrant lower class showed their opposition to the absolutist state and the ruling elites. Küther's study revolved around the idea of a Gegengesellschaft, a counter-society on the roads of eighteenth- and early nineteenth-century Germany. His book has been recognized as an important initial step towards the beginning of modem crime and criminal justice history in Germany; but critics soon followed, questioning the assumptions about social banditry and about a vagrant counter society, and explicitly rejecting Küther's views on the political and social aspects of banditry and vagrant criminals. As an alternative, banditry was conceived as a separate but compliant subculture ${ }^{6}$. The critics suggested that bandits were engaged in entrepreneurial activities that conformed to the norms of established society, rather than acting as noncommercial and thus 'alternative' entrepreneurs. But both Küther and his critics appreciated the significance of material values, organizational efficiency, division of labor, and so forth.

Blasius explored the social consequences of economic change for the lower strata of Prussian society in the first half of the nineteenth century. This was a period

6 Dancker (1988). 
when changes in the system of agricultural land ownership and land use, together with the abolition of the commons and the reinforcing of private landownership, led to the impoverishment of the lower social strata in the countryside. Many other European societies shared this experience. Blasius saw wood theft as an indicator of subsistence-criminality and as a form of resistance, exercised by the poor to defend the traditional rural economic and social system. Follow-up research has tried to elaborate this concept of 'social criminality' by examining, for example, rural criminality and wood theft in northwestern regions of Germany at the end of the eighteenth and the beginning of the nineteenth century, and by investigating the social organization and extent of theft in Hamburg harbor in the 1890s and the first quarter of the twentieth century. Wood theft was no longer understood as an indicator of cleavages between those 'on top' and those 'at the bottom' of rural societies, but was conceived as a result of conflicts within increasingly differentiated communities. The example of the Hamburg docks underlined the growing stratification of the working class and the efforts of working-class organizations to enforce non-criminal orderliness in the docks. It turned out that that high levels of union membership among dock workers correlated with low levels of criminality ${ }^{7}$.

\section{B. The Cultural Turn in German Crime and Criminal Justice History}

In the late 1980s German crime and criminal justice history shifted its focus significantly. Historiography in Germany abandoned its early focus on the social history of crime and replaced it with an approach that, broadly speaking, focused on the cultural meanings of crime ${ }^{8}$. This cultural approach has been applied predominantly to topics in the early modern and the Ancien Régime periods but it is now gradually penetrating work on the nineteenth-century ${ }^{9}$. The approach can be described as oriented towards investigating local and/or small urban communities, dealing with crime, conflict, justice and groups or behavioral patterns labeled as deviant. One of the first studies of this kind, published in 1991, analyzed crime and society in an early modern Cologne ${ }^{10}$. The book series which headlines this approach, containing not only publications on crime and criminal justice but also on the more general concept of deviance, runs under the title Konflikte und Kultur. Historische Perspektiven (Conflicts and Culture. Historical Perspectives); the first volume appeared in $1999^{11}$. In the introduction to the series, the editors explicitly stated their intention to be connecting the social history aspects of crime with cultural understandings of crime. To this end records from local and regional courts have been used to recon-

See the contributions in Reif (1984).

8 For another - literature and media orientated - approach to cultural meanings of crime see the contributions in Schönert (1983, 1991); Lindner (1999).

9 Habermas (2009); Schulte (1989), see also the collective volumes edited by Evans (1988); Berding, Klippel, Lottes (1999); Krug-Richter, Reinke (2004); Habermas, Schwerhof (2009). On the codification of penal in the German states during the $19^{\text {th }}$ century see Kesper-Biermann (2007). Quantitative approaches as in Zehr (1976) and in Johnson (1995) are not part of this new history of crime and criminal justice in Germany.

10 Schwerhoff (1991).

11 Among the volumes on crime and criminal justice in this series are Ludwig (2008); Bretschneider (2008); Hochmuth, Rau (2006); Schwerhoff (2005); Schwanke (2005); Kies (2004); Bendlage (2003); Henselmeyer (2002); Rudolph (2001); Groebner (2000); Dinges, Sack (2000); Blauert, Schwerhoff (2000); Häberlein (1999). 
struct the meanings that contemporary individuals attached to situations, interactions with other individuals, structures and (penal) norms. The idea is that the reconstruction of court proceedings via court records allows for the reconstruction of social relations and the meanings attached to these social relations. This constructivism is a feature which connects a number of early modern crime history studies, such as work on infanticide, on sexual offenses and property crime, but research also on violations of honor ${ }^{12}$.

The constructivist perspective and the emphasis on cultural meanings in German crime and criminal justice history have helped also to foster an alternative understanding of penal sanctions. This no longer understands death penalties, torture and other sanctions inflicted on the body of the delinquent as the main strategies to enhance societal norms and to punish the violation of laws; rather these are discretionary variations and as such they constitute the essential characteristic of the early modern and the Ancien Régime penal system. The significant selectivity in the application of sanctions has been understood as another indicator for understanding crime and criminal justice as social processes. The German historiography of crime and criminal justice now provides two interpretations for explaining the variations in inflicting sanctions on delinquents. The first explanatory line stresses the structural deficits of 'statehood' within and among the territories of early modern and Ancien Régime Germany, which made the enforcement of penal norms and sanctions difficult. The other line stresses the character of penal processes as exchange processes. A further perspective has been added which emphasizes the use of the courts for conflict resolution by two opposing sides in a dispute. The notions of 'exchange' and 'conflict resolution' indicates the extent to which modern research on German crime and criminal justice history perceives penal institutions not only as repressive control instruments and as a device for applying harsh sanctions, but also as a dispositive within social processes ${ }^{13}$.

A number of other areas of research cannot be left unmentioned: there have been significant studies of sexual offences ${ }^{14}$ and of sexually motivated serial murder ${ }^{15}$ which also address the cultural meanings of crime; the history of youth and of youth crime is orientated very much towards social-control approaches ${ }^{16}$. Additionally, there has been a growing interest on the history of crime policy (Kriminalpolitik) ${ }^{17}$, on the history of criminology ${ }^{18}$ and on the development of criminalistic techniques ${ }^{19}$.

12 See Schwerhoff (1999) and the contributions in Blauert, Schwerhoff (2000).

13 For a summary on then understanding of the penal as cultural and social processes see Schwerhoff (2000).

14 Hommen (1999).

15 Brückweh (2006).

16 Among these are Peukert (1986); Wolff (1992); Grotum (1994); Kenkmann (1996a); Kebbedies (2000); Briesen, Weinhauer (2007).

17 Oberwittler (2000); Schauz, Freitag (2007).

18 Wetzel (2000); Becker (2002); Galassi (2004); Müller (2004); Baumann (2006).

19 Regener (1999); Vec (2002); Becker (2005). 


\section{The early modern and Ancien Régime Policey in German Crime and Criminal Justice History}

Research on the early modern and Ancien Régime German concept of Policey has been extensive. The word Policey can be translated simply as 'police', but is best understood as a pre-modern theory and practice of government that aimed at the well-being of the population. Included in its model of good government were the control of, and the application of sanctions against those who opposed the intentions of the authorities.

A book by Maier, originally published in 1966, revised in 1980 and reprinted in 1986, was for some time the only significant contribution to research on Policey ${ }^{20}$. It held a position similar to that of Radbruch and Gwinner on the history of German crime and criminal justice. Drawing on the hundreds of ordinances, pamphlets, articles and books which circulated in the German states from the late seventeenth century, Maier suggested three main conclusions. First, he interpreted police as directly related to those concepts of authority which had been developed in the neo-Aristotelian thinking about the state since the high and later Middle Ages. Secondly, he emphasized a paradoxical shift by which the number and intensity of police regulations circulated in the seventeenth and eighteenth centuries served to restrict claims of absolute power. Thirdly, and as a consequence, he suggested that the intensification of policing was not so a means to expand state power and monarchical domination but rather, and unwittingly, a means to curb it.

Maier stuck to the legal rhetoric of the orders and largely ignored the practice which was stimulated and justified by claims of good police. As a consequence he did not take into account the various strands and sectors of disciplinary activities. Maier neither considered the discretionary dimension of police practice nor was he interested in the experiences and practices of the subjects of state - the masses that were policed. In recent years, however, research into a tremendous body of archival documentation has successfully filled the gap and has documented the extent to which, similar to early modern and Ancien Regime penal policies proper, Policey was not only a repressive control instrument, but also a pragmatic device for finding flexible answers to contemporary problems ${ }^{21}$.

\section{The History of the Prison}

The history of the prison and of other institutions of confinement has also gained a significant position in the history of German crime and criminal justice ${ }^{22}$. Falk Bretschneider's comprehensive history of the prison in Saxony during the eighteenth and nineteenth centuries might be acknowledged as the state of art in German prison history ${ }^{23}$. In this study the institutions of confinement, among them the prison, are no longer conceived as total institutions which force the inmates into

\footnotetext{
20 Maier (1986).

21 See for this the homepage of the Max-Planck-Institut für Europäische Rechtsgeschichte (Frankfurt/Main) and the links to the institute's documentation and research program on the Policeyordnungen of continental Europe. See also Härter (2000); Holenstein, Konersmann, Pauser, Sälter (2002).

22 Finzsch, Jütte (1996).

23 Bretschneider (2008).
} 
prescribed behavioral patterns and fixed and prescribed role models. Instead, the prison is understood as an institution that is not only influenced by the ways in which the 'outside' defines and structures the it, but by manifold internal social processes (Gefangene Gesellschaft / society in prison). These processes include power arrangements and the exercise of power as well as exchange processes between the prison administration and the prison guards on the one side and the inmates on the other. These exchange processes do not occur between members of the prison administration and the inmates alone but also, as Bretschneider observes, between the inmates themselves.

This view cannot be separated from a conceptual shift which occurred not only in German prison history but also in the history of the German police. In many of these studies one can find similar essentials that cluster around a denial of strict topdown perspectives, and that challenge the notions that conceive of criminal justice institutions - the police, the criminal courts, and the prison - as all-powerful and as able to enforce their will on those treated by them. This top-down-notion was, in part, influenced strongly by Max Weber's concept of Herrschaft (Domination), but it was also shaped by models of conflict theory which leaned significantly on Marxian ideas of class conflict. This shift away from top-down models has been partly the consequence of new research questions (see for this the section on German police histories below), and partly a follow-up from orientations towards Foucauldian notions of power (Macht), especially in the sense in which power is seen a medium that is accessible and/or can be used from different sides, not only by those on the top of political and social hierarchies, but also by those below.

The history of the prison in Germany not only clusters around conceptual models and grand theories, but engages also in solid institutional reconstructions and the internal practices. These reconstructions were all the more urgently needed, given that German prison history shared the late start that is characteristic of German crime and criminal justice history. The studies which have appeared recently cover a wide range of topics, such as the history of single prisons, the history of attempts to reform the prison and to improve the situation of the inmates ${ }^{24}$. Some of these studies show that the conventional wisdom about the development of the prison - at least in the German case - is open to question. Particularly problematic is a chronology which establishes the decades around 1800 as the period which experienced the gradual replacement of dehumanizing corporal punishments, including the philosophies and the strategies behind these punishments, with the rise of confinement. Some of the studies stress that confinement was a common practice long before 1800 and that the practice and the philosophy of corporal punishment lasted far into the twentieth century. Histories of the death penalty in Germany and a comprehensive project on the German prison during the Nazi period have shown further the extent to which dehumanizing strategies persisted - strategies that aimed rather at extinguishing the criminal offender or someone defined as deviant rather than bettering him by reforming him in confinement ${ }^{25}$.

24 Schauz (2008); Riemer (2005); Leukel (2004); Henze (2003); Nutz (2001), see also Ammerer, Bretschneider, Weiß (2003); Klewin, Reinke, Sälter (2008). Since 2008, the series Geschlossene Häuser. Historische Studien zu Zuchthäusern, Gefängnissen, Hospitälern und anderen Institutionen der Verwahrung focusses on prisons and other institutions of confinement (Leipzig, Leipziger Universitätsverlag).

25 Wachsmann (2004), see also Evans (1996); Martschukat (2000). 


\section{GERMAN POLICE DURING THE NINETEENTH AND TWENTIETH CENTURIES}

\section{A. Police in Germany during the Nineteenth and the early Twentieth centuries}

As a result of double dictatorship in twentieth-century Germany and the close relationships between police and politics during these periods, the history of political police and the politicalization of policing occupies a prominent place in German police history. But German police history is not restricted to this specific topic ${ }^{26}$. Police history is by far - at least quantitatively - the largest field within the overall history of crime and criminal justice in Germany ${ }^{27}$. A recent bibliography of book publications (monographs and edited volumes) comes close to two hundred titles, and this excludes the massive number of published studies on East German state security. In addition to the quantity, a number of qualitative aspects characterize this branch of crime and criminal justice history. Similar to approaches in other areas, police history has moved away from its early focus on top-down perspectives to address the functioning of the police. The emphasis here is on police interaction with the public, even on what might be termed as the dependence of the police on the public so as to establish what the police themselves considered to be efficient policing. This aspect has been stressed in a number of studies on the relations between the Gestapo and the German population during the Nazi period. Research on policing in the communist German Democratic Republic has also pointed to cooperative interaction between the police and the public. Another qualitative aspect is the involvement of members of the police institution in police history. Up until 1980 police history written by police existed largely as a kind of apologetic self defense, especially with reference to the role of the police during the Nazi period. Since the 1990s, however, a number of German police administrations have engaged in projects that have included the involvement of university-trained historians. These projects have examined critically, and without any restrictions, the respective administration's past ${ }^{28}$. These examinations have now been extended to the most important federal police administration in Germany, the Bundeskriminalamt. The latter has launched a project to explore its history from the 1950s to the 1970s. The focus is on the legacies of the Nazi period, and on what the continuities of personnel, crime control and prevention strategies meant for the work of the Bundeskriminalamt during these decades ${ }^{29}$.

The early history of the German police has been much less explored. There is one remarkable study by Siemann that explored the beginnings of political policing during the first half of the nineteenth century ${ }^{30}$. Siemann scrutinized the archival material of the various German states and of the German Federation from 1815 until

\footnotetext{
26 Nitschke (1996).

27 See the collective volumes edited by Lüdtke (1992); Reinke (1993).

28 On Hamburg Fangemann, Reifner, Steinborn (1987); Buhlan, Jung (2000), on the Cologne police: Schloßmacher (2006), on Bonn: Dams, Dönecke, Köhler (2007), on the Düsseldorf police, see also Kenkmann (1996b, 2001).

29 Bundeskriminalamt (2008).

30 Sieman (1985).
} 
the founding of the Second Reich in 1870-1871. He painstakingly reconstructed the phases and forms of the making of a modern political police in the German states. In doing so he revealed a special mode of interaction, if not of intimacy, among those police officials who were responsible for collecting and investigating evidence and for imprisoning any suspect. In his view, this small circle of men became an extralegal institution. The dynamics of their task only too easily placed their discretionary police powers beyond any limits. Interestingly enough, the Prussian authorities explicitly named this network of police officials as their model when they set out to crush the Social Democratic Party and to found a new a political police in 1878 .

Research on the police of the Kaiserreich (1870/1871-1918) focused in its early phase on the position of the police in the political system of the Empire and its role in economic and social conflicts. The understanding of the police in this work was considerably influenced by an understanding of the Kaiserreich as a fragile coalition between traditional elites (the military, the landed nobility, the state bureaucracy) and sectors of the new bourgeois elites, mainly the industrial entrepreneurs. In the economic and political system of the Kaiserreich, law-and-order maintenance by the police not only meant the control and suppression of criminality but also political policing in a straightforward sense, including the control of the working class and the suppression of its unions and political organizations ${ }^{31}$.

The first attempt at a comprehensive historical analysis of the police within the economic, political, and social structures of this period was published in 1980 by a political scientist ${ }^{32}$. In this book about the shaping of the state monopoly of power in Prussia between 1848 and 1914, Funk seeks to relate the organizational development of the police, including its everyday practices, to the structures of the contemporary Prussian political system. In particular, he attempts to locate police authority (Polizeigewalt) within the overall structures of the state's monopoly of power. Funk describes police development in Prussia as a correlate of the increasing economic, social, and political cleavages within the Kaiserreich. The ruling old, and the new Prussian elites sought to cope with the threats to the economic and social order, perceived as deriving from the working class, by a number of policies and strategies, among them the quantitative and qualitative increase of the state police. Funk describes this development (which included also efforts to increase the professionalization and the specialization of the police and attempts to strengthen police efficiency by gradually abolishing its welfare functions) as occurring alongside the gradual transformation of local police forces into state police units. These efforts were primarily directed against contemporary social movements rather than any increase in 'ordinary crime'. Thomas Lindenberger's research into the maintenance of law and order on the streets of Berlin in the decade before World War I gives a number of examples of how this strategy operated in the context of everyday policing activities ${ }^{33}$.

The growing bureaucratization of the police was a central aspect of police development in nineteenth-century Prussia. Funk was among the first to trace the details

31 On political policing, see also Evans (1989), Wilms (1992); on the role of the military: Johanson (2005), Müller (2005) on the mediatization of crime and the police, on the control and prosecution of minorities/male homosexuals Dobler (2008); and on the efforts to organize international police cooperation during that period Jäger (2006).

32 Funk (1986), see also Lüdtke (1982, English Version 1989).

33 Lindenberger (1995). 
of this bureaucratization and to reveal that it was not only a function of the institutional and organizational growth of the Prussian police in this period, but it was also a strategy to restrict police authority, in principle unlimited, by submitting it to bureaucratic rules of performance. Funk's arguments were developed by drawing extensively on source material from the Berlin police ${ }^{34}$.

Other research shifted the focus to other parts of Prussia, adding new perspectives to the overall picture and showing that the reality was far more complex than the usual Berlin-centered view suggests. A monograph on police development and the exercise of power in parts of the Ruhrgebiet between 1848 and 1914, focuses on a region of booming coal mines, steel industries and fast-growing urban agglomerations, which were characterised as the Prussian 'Wild West ${ }^{35}$. This region attracted large numbers of transient, unskilled young male workers recruited from eastern parts of Germany to work in the coal mines. On the basis of extremely good local archive material, Jessen describes the attempts to modernize and professionalize municipal police forces. He understands this modernization as a strategy to adapt the police to the growing control requirements created by urbanization patterns in the Ruhrgebiet. But municipal police development meant not only growing control strategies; a characteristic of 'big-city police' during this period was the persistence of large-scale welfare functions that linked police activities at the end of the nineteenth and beginning of the twentieth centuries to the Ancien Régime's Policey. These patterns resulted in overpolicing, which was abolished only gradually. In the decades before World War I welfare activities carried out by the police were increasingly replaced by the activities of professional welfare institutions, indicating innerand intraorganizational differentiation processes - something that touched the police as well.

Since the beginnings of research into the period between 1918 and 1933 a number of Leitmotive have guided the study of the Weimar Republic. These Leitmotive pertain to the structural constraints which impeded the democratic development of the Republic leading to its failure and the Nazi seizure of power. The structural conservatism of the Weimar Republic police - senior police officers, for example, were recruited predominantly from the Reichswehr - was counted among these constraints. The institutional and organizational developments of the Prussian police in the early years of the Republic were researched relatively early on, with the focus on the growth of the Prussian police in the turbulent years from 1918 to $1923^{36}$. One of the key elements of police development in the Weimar period was the creation of a paramilitary anti-riot unit, the Sicherheitspolizei or SIPO. The SIPO became the cornerstone of police development in Weimar Germany. It not only reflected the state's organizational response to the revolutionary turbulence of the immediate post-war period, but it also served as a paradigm for everyday policing in Weimar as militarytype behavior. The tactics and pattern became prevalent in the police - to some extent even more prevalent than in the pre-1918 period.

Follow-up studies have shown the extent to which these patterns characterized the Prussian police within the Weimar Republic, its recruitment, training, unions

\footnotetext{
34 For a comparative account see now Knöbl (1998).

35 Jessen (1991), see also Spencer (1992); Roth (1997).

36 Buder (1986).
} 
and political attitudes and orientation ${ }^{37}$. The analysis of political attitudes and orientations implicitly includes the question of whether the police was one of the structural constraints on democratic development in Weimar. Leßmann not only stresses that the ranks of the police officers were recruited more or less exclusively from the ranks of army officers with World War I experience, but he also describes in detail how military strategies and military behavior patterns were at the center of training practices in the Prussian police.

In contrast to the analysis of the political role of the police in the Weimar Republic, the study of the police and 'ordinary crime' has interested historians to a much lesser extent. Wagner's comprehensive study of the conceptions and the practices of the Kriminalpolizei during Weimar Republic and the Nazi period gives a summary account of the development of crime, particularly property crime, during these years. But the main focus of his book is on the way that the Kriminalpolizei radicalized its strategies and practices after the Nazi seizure of power up to the point where the fight against criminality meant the extermination of criminals ${ }^{38}$.

A number of studies emphasize the continuing impact of welfare notions on police strategies and activities during the Weimar Republic, stressing that repressive policing and welfare activities were something of a joint venture. Welfare policies and practices intended, for example, as aids for families, relied on rigid control of the behavior of those households that had become clients of the welfare agencies. During the 1920s, for example, the newly established female police acted as an institution not only to help endangered juveniles but also as agents for their surveillance and correction ${ }^{39}$.

\section{B. German Polices during the Nazi Period: Continuity, Rupture, or a New Terrain ${ }^{40}$}

For decades in West and East Germany interpretations of Fascism emphasized the actions of the dominant figures and/or elites that had cooperated with Nazism. Alternatively they stressed the constraints of socioeconomic and political structures. People and institutions below the heights of command within the polity and society passed for victims of both manipulation and terror. This view also offered a convenient way to explore the police and the criminal justice system. If German society in general, and numerous bodies and institutions in particular, had been forced to obey orders from above, then the police were no exception. Accordingly, the Nazi party and Nazi organizations had instrumentalized and 'abused' the police both as a body and as individuals. It was the Nazis who had imposed special laws and orders which nobody dared to resist. It was they who had implanted party members into the police apparatus; and it was they who had installed an apparatus that was perceived as an uncontrolled superpower of and within society, the Geheime Staatspolizei (Gestapo)

37 Leßmann (1989), see also Knatz (2000) and now Schmidt (2008); on political policing and surveillance during this period Dams (2002) and on police legislation Naas (2003).

38 Wagner (1996).

39 See the contributions on these welfare notions in Lüdtke (1992), on the female police, see Nienhaus (1999).

40 A summary of the institutional history of German polices during the Nazi period gives Wilhelm (1997). 
or Secret State Police. Accordingly, questions about the behavior of ordinary police officers were ignored.

The key questions were never asked: How could highly trained experts who were interested in the content of their work eagerly support policies for the brutal exclusion of "dangerous elements ${ }^{\text {" } 11}$ and, even worse, for the extermination of whole peoples? And as a follow on: Which modes of perception and which everyday practices made it possible that the overwhelming majority of police officials and state prosecutors, of judges and lawyers, not only stayed on but actively contributed to the execution of Nazi policies? In fact the police and the judiciary seem to have perceived the changes as the fulfillment of the goals that they had long sought.

The few studies which focus on the police after 1933 show that the overwhelming majority of them continued to perform their tasks in accordance with the orders and expectations of their superiors ${ }^{42}$. They accepted, if not supported, the exclusion of those marked as 'enemies' of the Reich and German Volk. Policemen themselves did not hesitate to label suspects as 'dangerous' and 'alien' to the people's community (Volksgemeinschaft). Most policemen readily participated in the persecution of these 'internal enemies'. For decades, the preventive detection and exclusion of presumed aliens had been a central feature of policing. To the police, public order in the locality blended seamlessly with the security of the Reich at large. This longstanding and well-accepted orientation was the convenient justification to expand the policing of public order on to new terrain ${ }^{43}$.

The emancipation of police from most restrictive limits of the law (or, more practically, from the interventions of judges or courts) was one of the Nazi roads toward 'rule by decree' (Massnahmestaat, according to Ernst Fraenkel) ${ }^{44}$. Some parts of the criminal police and, most actively, the Gestapo, claimed and acquired unchecked powers with reference to the detention of suspects ${ }^{45}$. Indeed after 1933 the police actively subverted the 'rule of law'. The normality of the daily repression of others weakened those scruples that might otherwise have hindered police participation in the Holocaust. To put it bluntly, the police actively and continuously contributed to sustaining Fascist domination. The Gestapo figures most prominently in the accounts of Nazi domination in general and Nazi terror in particular. The Gestapo developed in an arena of its own; it was created and safeguarded against competing agencies of both the state and the Nazi party. It was a bureaucratic apparatus dwelling at a distance from state and centralized power. During the first weeks of Nazi domination, in the process of their coordination (Gleichschaltung), the Gestapo homogenized the political police of the German states. The Gestapo law of 1936 confirmed the structure that had been established in 1933. Among the public, the Gestapo rapidly acquired the notoriety of being omnipresent. Such, at least, was the traditional picture. However, recent research has questioned this image. A study

41 Аyаß $(1995,1998)$.

42 Graf (1983); Fatz (1995).

43 See on this Fangmann, Reifner, Steinborn (1987); Buhlan (2000); Linck (2000); Goch (2005); Schloßmacher (2006); Dams, Dönecke, Köhler (2007).

44 Fraenkel (1969/1941).

45 On the relations between police and the criminal justice system during the Nazi period see Reifner, Sonnen (1984); Werle (1989); Gruchmann (1990); on the Gestapo see in particular the collective volumes edited by Paul, Mallmann (1995, 2000), now also Dams, Stolle (2008). 
by Reinhard Mann first raised doubts ${ }^{46}$. Using the files of the Stapostelle in Düsseldorf, Mann showed that at least one-third of the investigations by the Gestapo were triggered by information or denunciation from the general public. Second, the evidence also indicated that denunciations reached a peak from 1939 to 1941-1942, parallel to the Blitzkrieg and military success.

Two subsequent studies have confirmed Mann's findings. Robert Gellately published a broad-ranging, in-depth account of Gestapo activities drawing on material from the regional Düsseldorf (and the Cologne) Gestapo headquarters as well as that at Würzburg ${ }^{47}$. He argues convincingly that even in areas like Catholic Lower Franconia and the town of Würzburg, the enforcement of anti-Semitic policies was widely supported: 'A sufficient number of people [came] forward, for whatever reason, to offer information when they witnessed non-compliant behavior of any kind.' However, in this subtle and balanced account, it is not only the 'flood of denunciations' that is analyzed. Gellately also traces the surprising and enormous drop-back involving the surveillance and control of Poles during the war. And he discusses cases in which the Gestapo considered the reported, suspect, 'treasonous' behavior of individual Germans. This scrupulous account shows that anti-Semitism blended with traditional notions of respectability and orderliness to establish a common ground for compliance, not only with the Führer but with local Gestapo terror.

Klaus-Michael Mallmann and Gerhard Paul extended this view in their study of the whole spectrum of Nazi domination in the Saar area (the western part of the country, which had been under French control after 1919 and voted for Nazi Germany in $1935)^{48}$. The authors originally expected to show popular resistance to Nazism or, at least, a range of noncompliance. Their detailed analysis of people's everyday lives, however, compelled them to revise their assumptions. The result is a painstaking reconstruction of personnel, organization and practices at the local post (Stapostelle) in Saarbrücken. The authors show, for instance, that less than 50 percent of the rankand-file Gestapo officials were members of the Nazi party or Nazi organizations. Here, as elsewhere, many of the Gestapo officials were recruited from the criminal police. The likelihood that this background strengthened the Gestapo's ability to persecute political and racial adversaries is overrated, however. The authors emphasize the limits of the local Gestapo's professionalization by providing details of their bureaucratic mismanagement, not the least their inefficient card files of suspects. Mallmann and Paul also point to the inability of the local post to keep track of the flood of orders issued from the Gestapo head office in Berlin, the Gestapa (Geheimes Staatspolizeiamt). Indeed, during the war there appears to have been a degree of deprofessionalization as many experienced officials were transferred to the $S D$ (Sicherheitsdienst), the Secret Military Police. This account of the deficiencies and inefficiencies of a local post underlines the crucial role of support and cooperation among the broad majority of German citizens. Only people's readiness to pass on information can explain the Gestapo's relative success in crushing oppositional circles and penalising those guilty of non-compliance with Nazi policies.

The importance of cooperation and denunciation in the work of the Gestapo and the exchange between police and society led to the suggestion that Nazi Germany

\footnotetext{
46 Mann (1987).

47 Gellately (1990).

48 Mallmann, Paul (1991)
} 
was, to some extent, a self-policed society. Here again those top-down perspectives, which had already been scrutinized in other fields of German crime and criminal justice history, were questioned. But increasingly, this social history of terror has been critically examined with stress, once again, on the terror exercised by the Gestapo ${ }^{49}$.

There has also been much intensive research into what led 'ordinary men' into active participation in mass murder. There is now a solid stock of knowledge about the involvement of members of the 'ordinary' police (Ordnungspolizei) in the mass murder of the Jewish population of Europe during the Second World War ${ }^{50}$. The results of this research have had a considerable impact on a relatively new interdisciplinary field: Täterforschung (research on perpetrators) crosses of a number of academic disciplines, including crime and criminal justice history ${ }^{51}$.

\section{Police in Germany after 1945}

For the victorious allies, the police of Nazi Germany was one of the institutions which had to be controlled and subjugated for an effective military government of occupied Germany. But the allied forces not only wanted control; they wanted also completely to reconstruct the German police. Although in practice each of the allies proceeded differently in its zone, certain general principles were agreed on, such as the abolition of the Gestapo, the dismissal of Nazis among police personnel, and the complete reversal of the centralizing policy pursued by the Nazis with reference to the police. In the British zone this reversal led, more or less, to a complete abolition of the traditional German police system. The military government and the German authorities alike aimed at implementing what was perceived as the English model. They replaced state police by local and communal police forces.

These developments have led official German police historiography to characterize the years after 1945 as a 'new start' for the police ${ }^{52}$, but other research has emphasized the continuities ${ }^{53}$. The abolition of all communal and local police forces and, during the early years of the Federal Republic, the reintroduction and remilitarization of riot police units which were shaped, according to the riot police model established by the Prussian government of the Weimar Republic, were seen as indicators of the continuities. More recent research describes how changes in the overall functioning of the police, which had been introduced by the British and American Military Administrations, were maintained alongside questionable continuities, most notably in regard to the personnel of the police ${ }^{54}$. Police developments in the $1950 \mathrm{~s}$ and the $1960 \mathrm{~s}$, and even the response to the terrorist movements in the 1970s, have also been subjected to the historian's gaze ${ }^{55}$.

\footnotetext{
49 Paul (1996); Wysocki (1997); Dörner (1998); Johnson (2000); Lotfi (2000); Berschel (2001); Stolle (2001), for an overall account on denunciations also Lüdtke, Fürmetz (1998).

$50 \quad$ Lichtenstein (1990); Browning (1992); Klemp (1998, 2005); Curilla (2006).

51 Paul (2002); Mallmann, Paul (2004); Welzer (2005); Wette (2004).

52 Hamacher (1989).

53 Werkentin (1984), also very critical Steinborn, Krüger (1993); Steinborn (2000); Boldt (2002), also the contributions in Groh (2002), for an overall account of the German police in the two German states after 1945 up to the 1960s, see Fürmetz, Reinke, Weinhauer (2001).

54 Noethen (2003); Wagner (2002).

55 Weinhauer (2003); Weinhauer, Requate, Haupt (2006).
} 
Since the fall of the Berlin Wall and reunification, the history of policing in communist Eastern Germany has focused predominantly on studies of the political police of the German Democratic Republic, the Staatssicherheit/Stasi (state security). Research and publications on the $S t a s i^{56}$ vastly outnumber those on the ordinary Volkspolizei of the GDR ${ }^{57}$.

\section{A BRIEF CONCLUDING REMARK}

Since its late start in the mid-1970s, research into the history of crime and criminal justice in Germany has rapidly expanded. The history of early modem crime and criminal justice, and the later development of police in particular, have stimulated increasing interest among German scholars. Other lacunae shrink as, for example, in the case of prison history. A late start sometimes has substantial advantages. Large sections of German crime and criminal justice hisotry now operate on an understanding that claims about control, conflicts, justice and so forth, are part of cultural and social processes. Foucault's plea for conceptualizing power as a set of relationships beyond institutional settings has been subsumed ${ }^{58}$, taking into account social actors and the uneven distribution of capacities which either enable or hinder people to act 'powerfully'. It looks as if crime and criminal justice history in Germany has reached the stage of 'normal science'.

Herbert Reinke

Elberfelder Str. 35

D-10555 Berlin

herbert.reinke@tu-berlin.de

\section{BIBLIOGRAPHY}

Ammerer, G., Bretschneider, F., Weiß, A. St. (eds), Gefängnis und Gesellschaft. Zur (Vor-) Geschichte der strafenden Einsperrung, Leipzig, Leipziger Universitätsverlag, 2003. Ayaß, W., «Asoziale» im Nationalsozialismus, Stuttgart, Klett-Cotta, 1995.

Ayaß, W., «Gemeinschaftfremde». Quellen zur Verfolgung von «Asozialen» 1933-1945, Koblenz, Bunderarchiv, 1998.

Baumann, I., Dem Verbrechen auf der Spur. Eine Geschichte der Kriminologie und Kriminalpolitik Deutschland, 1880-1980, Göttingen, Wallstein, 2006.

Becker, P., Verderbnis und Entartung. Eine Geschichte der Kriminologiedes 19. Jahrhunderts als Diskurs und Praxis, Göttingen, Vandenhoeck \& Ruprecht, 2002.

Becker, P., Dem Täter auf der Spur. Eine Geschichte der Kriminalistik, Darmstadt, Wissenschaftliche Buchgesellschaft, 2005.

56 For a summarizing account on the Stasi, see Gieseke (2001), also Gieseke (2000) on the personnel of the Stasi.

57 Lindenberger (2003).

58 In Lüdtke, Reinke (1996, p. 127), this statement still reads as «However, Michel Foucault's plea for studying power as a fluid set of relationships and, thus, for considering the ubiquity of domination in modem society beyond institutional settings has mostly been ignored». 
Bendlage, A., Henkers Hetzbruder. Das Strafverfolgungspersonal der Reichsstadt Nürnberg im 15. und 16. Jahrhundert, Konstanz, Universitätsverlag Konstanz, 2003.

Berding, H, Klippel, D., Lottes, G. (eds), Kriminalität und abweichendes Verhalten. Deutschland im 18. und 19. Jahrhundert, Göttingen, Vandenhoeck \& Ruprecht, 1999.

Berschel, H., Bürokratie und Terror. Das Judenreferat der Gestapo Düsseldorf 1935-1945, Essen, Klartext Verlag, 2001.

Blasius, D., Bürgerliche Gesellschaft und Kriminalität. Zur Sozialgeschichte Preußens im Vormärz, Göttingen, Vandenhoeck \& Ruprecht, 1976.

Blasius, D., Kriminalität und Alltag. Zur Konfliktgeschichte des Alltagslebens im 19. Jahrhundert, Göttingen, Vandenhoeck \& Ruprecht, 1978.

Blauert, A., Schwerhoff, G. (eds), Kriminalitätsgeschichte. Beiträge zur Sozial- und Kulturgeschichte der Vormoderne, Konstanz, Universitätsverlag Konstanz, 2000.

Boldt, E. B., Die verschenkte Reform. Der Neuaufbau der Hamburger Polizei zwischen Weimarer Tradition und den Vorgaben der britischen Besatzungsmacht, Hamburg, Lit Verlag, 2002.

Bretschneider, F., Gefangene Gesellschaft. Eine Geschichte der Einsperrung in Sachsen im 18. und 19. Jahrhundert, Konstanz, Universitätsverlag Konstanz, 2008.

Briesen, D., Weinhauer, K. (eds), Jugend, Delinquenz und gesellschaftlicher Wandel. Bundesrepublik Deutschland und USA nach dem Zweiten Weltkrieg, Essen, Klartext Verlag, 2007.

Browning, Ch. R., Ordinary Men: Reserve Police Battalion 101 and the Final Solution in Poland, New York, Harper Collins, 1992.

Brückweh, K., Mordlust. Gewalt und Emotionen im 20. Jahrhundert, Frankfurt/Main, Campus Verlag, 2006.

Buder, J., Die Reorganisation der preußischen Polizei 1918-1923, Frankfurt/Main, Peter Lang, 1986.

Buhlan, H., Jung, W. (eds), Wessen Freund und wessen Helfer? Die Kölner Polizei im Nationalsozialismus, Köln, Emons, 2000.

Bundeskriminalamt (ed.), Das Bundeskriminalamt stellt sich seiner Geschichte. Dokumentation einer Kolloquienreihe, Köln, Luchterhand Verlag, 2008.

Curilla, W., Die deutsche Ordnungspolizei und der Holocaust im Baltikum und in Weißrussland 1941-1944, Paderborn, Fetdinand Schöningh, 2006.

Dancker, U., Räuberbanden im Alten Reich um 1700. Ein Beitrag zur Geschichte von Herrschaft und Kriminalität in der frühen Neuzeit, Frankfurt/Main, Suhrkamp Verlag, 1988.

Dams, C., Staatsschutz in der Weimarer Republik, Die Überwachung und Bekämpfung der NSDAP durch die preußische politische Polizei von 1928-1932, Marburg, Tectum Verlag, 2002.

Dams, C., Dönecke, K., Köhler, Th. (eds), «Dienst am Volk»? Düsseldorfer Polizisten zwischen Demokratie und Diktatur, Frankfurt/Main, 2007.

Dams, C., Stolle, M., Die Gestapo. Herrschaft und Terror im Dritten Reich, München, C.H. Beck, 2008.

Dinges M., Sack, F. (eds), Unsichere Großstädte. Vom Mittelalter bis zur Postmoderne, Konstanz, Universitätsverlag Konstanz, 2000.

Dobler, J., Zwischen Duldungspolitik und Verbrechensbekämpfung. Homosexuellenverfolgung durch die Berliner Polizei von 1848 bis 1933, Frankfurt/Main, Verlag für Polizeiwissenschaft, 2008.

Dörner, B., «Heimtücke»: Das Gesetz als Waffe. Kontrolle, Abschreckung und Verfolgung in Deutschland 1933-1945, Paderborn, Ferdinand Schöningh, 1998. 
Evans, R. J. (ed.): Kneipengespräche im Kaiserreich, Stimmungsberichte der Hamburger Politischen Polizei, Reinbek, Rowohlt, 1989.

Evans, R. J., Rituals of Retribution. Capital Punishment in Germany 1600-1987, Oxford, Oxford University Press, 1996.

Fangemann, H., Reifner, U., Steinborn, N., «Parteisoldaten». Die Hamburger Polizei im «3. Reich», Hamburg, VSA Verlag, 1987.

Fatz, M., Vom Staatsschutz zum Gestapo-Terror. Politische Polizei in Bayern in der Endphase der Weimarer Republik und der Anfangsphase der nationalsozialistischen Diktatur, Würzburg, Echter Verlag, 1995.

Finzsch, N, Jütte, N. (eds), Institutions of Confinement. Hospitals, Asylums, and Prisons in Western Europe and North America, 1500-1950, Cambridge, Cambridge University Press, 1996.

Fraenkel, E., The Dual State. A Contribution to the Theory of Dictatorship, New York, Octogan Books, 1969 (1941).

Fürmetz, G., Reinke, H., Weinhauer, K. (ed.), Nachkriegspolizei. Sicherheit und Ordnung in Ost- und Westdeutschland 1945-1969, Hamburg, Dölling und Galitz Verlag, 2001.

Funk, A., Polizei und Rechtsstaat. Die Entwicklung des staatlichen Gewaltmonopols in Preußen 1848-1914, Frankfurt/Main, Campus Verlag, 1986.

Galassi, S., Kriminologie im Deutschen Kaiserreich. Geschichte einer gebrochenen Verwissenschaftlichung, Stuttgart, 2004.

Gellately, R., The Gestapo and German Society. Enforcing Racial Policy, 1933-1945, Oxford, Clarendon Press, 1990.

Gieseke, J., Die hauptamtlichen Mitarbeiter der Staatssicherheit. Personalstruktur und Lebenswelt 1950-1989/90, Berlin, Ch. Links Verlag, 2000.

Gieseke, J., Mielke-Konzern. Die Geschichte der Stasi 1945-1990, Stuttgart, Deutsche Verlagsanstalt, 2001.

Goch, St. (ed.), Städtische Gesellschaft und Polizei. Beiträge zur Sozialgeschichte der Polizei in Gelsenkirchen, Essen, Klartext Verlag, 2005.

Graf, Ch., Politische Polizei zwischen Demokratie und Diktatur. Die Entwicklung der preußischen Politischen Polizei vom Staatsschutzorgan der Weimarer Republik zum Geheimen Staatspolizeiamt des Dritten Reiches, Berlin, Colloquium Verlag, 1983.

Groebner, V., Gefährliche Geschenke. Ritual, Politik und die Sprache der Korruption in der Eidgenossenschaft im späten Mittelalter und am Beginn der Neuzeit, Konstanz, Universitätsverlag Konstanz, 2000.

Grotum, Th., Die Halbstarken. Zur Geschichte einer Jugendkultur der 50er Jahre, Frankfurt/Main, Campus Verlag, 1994.

Groh, Ch. (ed.), Öffentliche Ordnung in der Nachkriegszeit, Ubstadt-Weiher, Verlag regionakultur 2002.

Gruchmann, L., Justiz im Dritten Reich 1933-1940. Anpassung und Unterwerfung in der Ära Gürtner, München, Oldenbourg Verlag, 2nd edition, 1990.

Habermas, R., Diebe vor Gericht. Die Entstehung der modernen Rechtsordnung im 19. Jahrhundert, Frankfurt/Main, Campus Verlag, 2008.

Habermas, R., Schwerhoff, G. (eds), Verbrechen im Blick. Perspektiven der neuzeitlichen Kriminalitätsgeschichichte, Frankfurt/Main, Campus Verlag, 2009 (forthcoming).

Häberlein, M. (ed.), Devianz, Widerstand und Herrschaftspraxis in der Vormoderne. Studien $z u$ Konflikten im südwestdeutschen Raum (15.-18. Jahrhundert), Konstanz, Universitätsverlag Konstanz, 1999.

Härter, K. (ed.), Policey und frühneuzeitliche Gesellschaft, Frankfurt/Main, Vittorio Klostermann Verlag, 2000. 
Hamacher, H.-W. (ed.), Polizei 1945 - ein neuer Anfang. Zeitzeugen erinnern sich, Hilden, Verlag Deutsche Polizeiliteratur, 2nd. printing, 1989.

Henselmeyer, U., Ratsherren und andere Delinquenten. Die Rechtssprechungspraxis bei geringfügigen Delikten im spätmittelalterlichen Nürnberg, Konstanz, Universitätsverlag Konstanz, 2002.

Henze, M., Strafvollzugsreformen im 19.Jahrhundert. Gefängniskundlicher Diskurs und staatliche Praxis in Bayern und Hessen-Darmstadt, Marburg, 2003.

Hochmuth, Ch., Rau, S. (eds), Machträume der frühneuzeitlichen Stadt, Konstanz, Universitätsverlag Konstanz, 2006.

Holenstein, A., Konersmann, F., Pauser, G., Sälter, G. (eds), Policey in lokalen Räumen. Sicherheitspersonal in Gemeinden und Territorien vom Spätmittelalter bis zum frühen 19. Jahrhundert, Frankfurt/Main, Vittorio Klostermann Verlag, 2002.

Hommen T., Sittlichkeitsverbrechen. Sexuelle Gewalt im Kaiserreich, Frankfurt/Main, Campus Verlag, 1999.

Jäger, J., Verfolgung durch Verwaltung. Internationales Verbrechen und internationale Polizeikooperation 1880-1933, Konstanz, Universitätsverlag Konstanz, 2006.

Jessen, R., Polizei im Industrierevier. Modernisierung und Herrschaftspraxis im westfälischen Ruhrgebiet 1948-1914, Göttingen, Vandenhoeck \& Ruprecht, 1991.

Johanson, A., Soldiers as Police. The French and Prussian Armies and the Policing of Popular Protest, 1889-1914, Aldershot, Ashgate, 2005.

Johnson, E. A., Urbanization and Crime. Germany 1871-1914, Cambridge, Cambridge University Press, 1995.

Johnson, E. A., Nazi Terror. The Gestapo, Jews and Ordinary Germans, New York, Basic Books, 2000.

Kebbedies, F., Außer Kontrolle. Jugendkriminalpolitik in der NS-Zeit und der frühen Nachkriegszeit, Essen, Klartext Verlag, 2000.

Kenkmann, A., Wilde Jugend. Lebenswelt großstädtischer Jugendlicher zwischen Weltwirtschaftskrise, Nationalsozialismus und Währungsreform, Essen, Klartext Verlag, 1996a.

Kenkmann, A. (ed.), Villa ten Hompel - Sitz der Ordnungspolizei im Dritten Reich. Vom «Tatort Schreibtisch» zur Erinnerungsstätte, Münster, Agenda Verlag, 1996b.

Kenkmann, Spieker, A. Ch. (ed.), Im Auftrag. Polizei, Verwaltung und Verantwortung, Essen, Klartext Verlag, 2001.

Kesper-Biermann, S., Die Kodifikation des Strafrechts. Ideen, Experten und Gesetzgebung in den deutschen Staaten des 19. Jahrhunderts, Justus-Liebig-Universität Gießen, 2007 (unpublished habilitation).

Kies, T., Verweigerte Moderne. Zur Geschichte der, Salpeterer' im 19. Jahrhundert, Konstanz, Universitätsverlag Konstanz, 2004.

Klemp, St., Freispruch für das «Mordbataillon». Die NS-Ordnungspolizei und die Nachkriegsjustiz, Münster, Lit Verlag, 1998.

Klemp, St., «Nicht ermittelt». Polizeibataillone und die Nachkriegsjustiz - Ein Handbuch, Essen, Klartext Verlag, 2005.

Klewin, S., Reinke, H., Sälter, G. (eds), Hinter Gittern. Zur Geschichte der Inhaftierung zwischen Bestrafung, Besserung und (politischem Ausschluß), Leipzig, Leipziger Universitätsverlag, 2008.

Knatz, Ch., «Ein Heer im grünen Rock»? Der Mitteldeutsche Aufstand 1921, die preußische Schutzpolizei und die Frage der inneren Sicherheit in der Weimarer Republik, Berlin, 2000 
Knöbl, W., Polizei und Herrschaft im Modernisierungsprozess. Staatsbildung und innere Sicherheit in Preußen, England und Amerika 1700-1914, Frankfurt/Main, Campus Verlag, 1998.

Krug-Richter, B., Reinke, H. (eds), Von rechten und unrechten Taten: Zur Kriminalitätsgeschichte Westfalens von der frühen Neuzeit bis zum 20.Jahrhundert, Münster, Aschendorffsche Verlagsbuchhandlung, 2004 (= Westfälische Forschungen, vol. 54/2004).

Küther, C., Räuber und Gauner in Deutschland. Das organsierte Bandenwesen im 18. und frühen 19. Jahrhundert, Göttingen, Vandenhoeck \& Ruprecht, 1976.

Küther, C., Menschen auf der Straße. Vagierende Unterschichten in Bayern, Franken und in Schwabe, in der zweiten Hälfte des 18. Jahrhunderts, Göttingen, Vandenhoeck \& Ruprecht, 1983.

Leßmann, P., Die preußische Schutzpolizei in der Weimarer Republik. Streifendienst und Straßenkampf, Düsseldorf, Droste, 1989.

Leukel, S., Frauenstrafanstalt und Frauenstrafvollzug im neunzehnten Jahrhundert (Baden und Preußen), Phil. Diss., Bielefeld, 2004.

Lichtenstein, H., Himmlers grüne Helfer. Die Schutz- und Ordnungspolizei im «Dritten Reich», Köln, Bund-Verlag, 1990.

Linck, St., Der Ordnung verpflichtet. Deutsche Polizei 1933-1949. Der Fall Flensburg, Paderborn, Ferdinand Schöningh, 2000.

Lindenberger, Th., Straßenpolizei. Zur Sozialgeschichte der öffentlichen Ordnung in Berlin 1900 bis 1914, Bonn, Verlag J.H.W. Dietz Nachf., 1995.

Lindenberger, Th., Volkspolizei. Herrschaftspraxis und öffentliche Ordnung im SED-Staat 1952-1968, Köln, Böhlau, 2003.

Lindner, J., Ort, C.-M. (ed.), Verbrechen - Justiz - Medien. Konstellationen in Deutschland von 1900 bis zur Gegenwart, Tübingen, Max Niemeyer Verlag, 1999.

Lotfi, G., KZ der Gestapo. Arbeitserziehungslager im Dritten Reich, Stuttgart. Deutsche Verlags-Anstalt, 2000.

Ludwig, U., Das Herz der Justitia. Gestaltungspotentiale territorialer Herrschaft in der Strafrechts- und Gnadenpraxis am Beispiel Kursachsens 1548-1648, Konstanz, Universitätsverlag Konstanz, 2008.

Lüdtke, A., «Gemeinwohl», Polizei und «Festungspraxis». Staatliche Gewaltsamkeit und innere Verwaltung in Preußen, 1815-1850, Göttingen, Vandenhoeck \& Ruprecht, 1982 (English version: Police and State in Prussia, 1815-1850, Cambridge, Cambridge University Press, 1989).

Lüdtke, A. (ed.), «Sicherheit» und «Wohlfahrt». Polizei, Gesellschaft und Herrschaft im 19. und 20. Jahrhundert, Frankfurt/Main, Suhrkamp Verlag, 1992.

Lüdtke, A., Reinke, H., Crime, Police, and the «Good Order»: Germany, in Emsley, C., Knafla, L. A. (eds), Crime History and Histories of Crime. Studies in the Historiography of Crime and Criminal Justice in Modern History, Westwood, Greenwood Press, 1996, pp. 109-137.

Lüdtke, A., Fürmetz, G. (ed.), Denunzianten in der Neuzeit. Politische Teilnahme oder Selbstüberwachung [Sozialwissenschaftliche Informationen, 27, 1998].

Maier, H., Die ältere deutsche Staats- und Verwaltungslehre, München, dtv wissenschaft, 1986 (1966).

Mallmann, K.-M., Paul, G., Herrschaft und Alltag. Ein Industrierevier im Dritten Reich, Bonn, Verlag J.H.W. Dietz Nachf., 1991.

Mallmann, K.-M., Paul, G. (eds), Karrieren der Gewalt. Nationalsozialistische Täterbiographien, Darmstadt, Wissenschaftliche Buchgesellschaft, 2004. 
Mann, R., Protest und Kontrolle im Dritten Reich. Nationalsozialistische Herrschaft im Alltag einer rheinischen Großstadt, Frankfurt/Main, Campus Verlag, 1987.

Martschukat, J., Insziniertes Töten. Eine Geschichte der Todesstrafe vom 17. bis zum 19. Jahrhundert, Köln, Böhlau, 2000.

Müller, Ch., Verbrechensbekämpfung im Anstaltsstaat. Psychiatrie, Kriminologie und Strafrechtsreform 1871-1933, Göttingen, Vandenhoeck \& Ruprecht, 2004.

Müller, Ph., Auf der Suche nach dem Täter. Die öffentliche Dramatisierung von Verbrechen im Berlin des Kaiserreichs, Frankfurt/Main, Campus Verlag, 2005.

Naas, St., Die Entstehung des Preußischen Polizeiverwaltungsgesetzes von 1931. Ein Beitrag zur Geschichte des Polizeirechts in der Weimarer Republik, Tübingen, Max Niemeyer Verlag, 2003.

Nienhaus, U., «Nicht für eine Führungsposition geeignet...»Josephine Erkens und die Anfänge weiblicher Polizei in Deutschland 1923-1933, Münster, Westfälisches Dampfboot, 1999.

Nitschke, P. (ed.), Die deutsche Polizei und ihre Geschichte. Beiträge zu einem distanzierten Verhältnis, Hilden, Verlag Deutsche Polizeiliteratur, 1996.

Noethen, St., Alte Kameraden und neue Kollegen. Polizei in Nordrhein-Westfalen 19451953, Essen, Klartext Verlag, 2003.

Nutz, Th., Strafanstalt als Besserungsmaschine. Reformdiskurs und Gefängniswissenschaft 1775-1848, München, Oldenburg Verlag, 2001.

Oberwittler, D., Von der Strafe zur Erziehung? Jugendkriminalpolitik in England und Deutschland (1850-1920), Frankfurt/Main, Campus Verlag, 2000.

Paul, G., Staatlicher Terror und gesellschaftliche Verrohung. Die Gestapo in SchleswigHolstein, Hamburg, Ergebnisse Verlag, 1996.

Paul, G., Die Täter der Shoah. Fanatische Nationalsozialisten oder ganz normale Deutsche?, Göttingen, Wallstein, 2002.

Paul, G., Mallmann; K.-M., (eds), Die Gestapo - Mythos und Realität, Darmstadt, Wissenschaftliche Buchgesellschaft, 1995.

Paul, G., Mallmann, K.-M., (eds), Die Gestapo im Zweiten Weltkrieg, Heimatfront und 'besetztes' Europa, Darmstadt, Wissenschaftliche Buchgesellschaft, 2000.

Peuckert, D.J.K., Grenzen der Sozialdisziplinierung. Aufstieg und Krise der Jugendfürsorge 1878-1932, Köln, Bund-Verlag, 1986.

Radbruch, G., Gwinner, H., Geschichte des Verbrechens. Versuch einer historischen Kriminologie, Frankfurt/Main, Eichborn Verlag, 1991 (1951).

Regener, S., Fotographische Erfassung. Zur Geschichte medialer Konstruktion des Kriminellen, München, Wilhelm Fink Verlag, 1999.

Reif, H. (ed.), Räuber, Volk und Obrigkeit. Studien zur Geschichte der Kriminalität in Deutschland seit dem 18. Jahrhundert, Frankfurt/Main, Suhrkamp Verlag, 1984.

Reifner, U., Sonnen, B.-R. (eds), Strafjustiz und Polizei im Dritten Reich, Frankfurt/Main, Campus Verlag, 1984.

Reinke, H. (ed.), «... nur für die Sicherheit da...»? Zur Geschichte der Polizei im 19. und 20. Jahrhundert, Frankfurt, Campus Verlag, 1993.

Riemer, L. H., Das Netzwerk der «Gefängnisfreunde» (1830-1872). Karl-Josef Anton Mittermaiers Briefwechsel mit europäischen Strafvollzugsexperten, Frankfurt/Main, 2005.

Roth A., Kriminalitätsbekämpfung in deutschen Großstädten 1850-1914. Ein Beitrag zur Geschichte des strafrechtlichen Ermittlungsverfahrens, Berlin, Erich Schmidt Verlag, 1997.

Rudoph, H., Eine gelinde Regierungsart. Peinliche Strafjustiz im geistlichen Territorium. Das Hochstift Osnabrück (1716-1803), Konstanz, Universitätsverlag Konstanz, 2001. 
Schauz, D., Freitag, S. (eds), Verbrecher im Visier der Experten. Kriminalpolitik zwischen Wissenschaft und Praxis im 19. und frühen 20. Jahrhundert, Stuttgart, Franz Steiner Verlag, 2007.

Schauz, D., Strafen als moralische Besserung. Eine Geschichte der Straffälligenfürsorge (1777-1933), München, 2008.

Schloßmacher N. (ed.), «Kurzerhand die Farbe gewechselt». Die Bonner Polizei im Nationalsozialismus, Bonn, 2006.

Schmidt, D., Schützen und Dienen. Polizisten im Ruhrgebiet in Demokratie und Diktatur 1919-1933, Essen, Klartext Verlag, 2008.

Schönert, J. (ed.), Literatur und Kriminalität. Die gesellschaftliche Erfahrung von Verbrechen und Strafverfolgung als Gegenstand des Erzählens. Deutschland, England und Frankreich 1850-1880, Tübingen, Max Niemeyer Verlag, 1983.

Schönert, J. (ed.), Erzählte Kriminalität. Zur Typologie und Funktion von narrativen Darstellungen in Strafrechtspflege, Publizistik und Literatur zwischen 1770-1920, Tübingen, Max Niemeyer Verlag, 1991.

Schulte, R., Das Dorf im Verhör. Brandstifter, Kindsmörderinnen und Wilderer vor den Schranken des bürgerlichen Gerichts, Reinbek, Rowohlt Verlag, 1989.

Schwanke, I., Fremde in Offenburg. Religiöse Minderheiten und Zuwanderer in der Frühen Neuzeit, Konstanz, Universitätsverlag Konstanz, 2005.

Schwerhoff, G., Köln im Kreuzverhör. Kriminalität, Herrschaft und Gesellschaft in einer frühneuzeitlichen Stadt, Bonn, Bouvier Verlag, 1991.

Schwerhoff, G., Aktenkundig und gerichtsnotorisch. Einführung in die historische Kriminalitätsforschung, Tübingen, Edition diskord, 1999.

Schwerhoff, G., Kriminalitätsgeschichte im deutschen Sprachraum. Zum Profil eines 'verspäeten' Forschungszweiges, in Blauert, A., Schwerhoff, G. (eds), Kriminalitätsgeschichte. Beiträge zur Sozial- und Kulturgeschichte der Vormoderne, Konstanz, Universitätsverlag Konstanz, 2000, pp. 21-52.

Schwerhoff, G., Zungen wie Schwerter. Blasphemie in alteuropäischen Gesellschaften, Konstanz, Universitätsverlag Konstanz, 2005.

Spencer, E. G., Police and the Social Order in German Cities : The Düsseldorf District, 18481914, DeKalb, Northern Illinois University Press, 1992.

Sieman, W., Deutschlands Ruhe, Sicherheit und Ordnung. Die Anfänge der politischen Polizei 1806-1866, Tübingen, Niemeyer, 1985.

Steinborn, N., Die Hamburger Polizei nach 1945 - Ein Neuanfang, der keiner war, Hamburg, Verlag Heiner Biller, 2000.

Steinborn, N., Krüger, H., Die Berliner Polizei 1945 bis 1952. Von der Militärreserve im Kalten Krieg auf dem Weg zur bürgernahen Polizei, Berlin,1993.

Stolle, M., Die Geheime Staatspolizei in Baden. Personal, Organisation, Wirkung und Nachwirkung einer regionalen Verfolgungsbehörde im Dritten Reich, Konstanz, Universitätsverlag Konstanz, 2001.

Vec, M., Die Spur des Täters. Methoden der Identifikation in der Kriminalistik (1879-1933), Baden-Baden, Nomos-Verlag, 2002.

Wachsmann, N., Hitler's Prisons. Legal Terror in Nazi Germany, New Haven, Yale University Press, 2004.

Wagner, P., Volksgemeinschaft ohne Verbrecher. Konzeptionen und Praxis der Kriminalpolizei in der Zeit der Weimarer Republik und des Nationalsozialismus, Hamburg, Hans Christians Verlag, 1996.

Wagner, P., Hitlers Kriminalisten. Die deutsche Kriminalpolizei und der Nationalsozialismus, München, C.H. Beck, 2002. 
Weinhauer, K., Schutzpolizei in der Bundesrepublik. Zwischen Bürgerkrieg und Innerer Sicherheit: Die turbulenten sechziger Jahre, Paderborn, Ferdinand Schöningh, 2003.

Weinhauer, K., Requate, J., Haupt, H.-G. (eds), Terrorismus in der Bundesrepublik, Medien, Staat und Subkulturen in den 1970er Jahren, Frankfurt/Main, Campus Verlag, 2006.

Welzer, H., Täter. Wie aus ganz normalen Menschen Massenmörder werden, Frankfurt/Main, 2005.

Werkentin, F., Die Restauration der Deutschen Polizei. Innere Rüstung von 1945 bis zur Notstandsgesetzgebung, Frankfurt/Main, Campus Verlag, 1984.

Werle, G., Justiz-Strafrecht und polizeiliche Verbrechensbekämpfung im Dritten Reich, Berlin, de Gruyter, 1989.

Wolff, J., Jugendliche vor Gericht im Dritten Reich. Nationalsozialistische Jugendstrafrechtspolitik und Justizalltag, München, C.H. Beck, 1992.

Wette, W. (ed.), Zivilcourage. Empörte, Helfer und Retter aus Wehrmacht, Polizei und SS, Frankfurt/Main, Fischer Taschenbuch Verlag, 2004.

Wetzell, R. F., Inventing the Criminal. A History of German Criminology, 1880-1945, Chapel Hill, The University of North Carolina Press, 2000.

Wilhelm, F., Die Polizei im NS-Staat. Die Geschichte ihrer Organisation im Überblick, Paderborn, Ferdinand Schöningh, 1997.

Wilms, B., Politische Polizei und Sozialdemokratie im Deutschen Kaiserreich.Zur Tätigkeit der Politischen Polizei in der Provinz. Hannover von der Zeit der Reichsgründung bis zum Ende des Sozialistengesetzes 1871-1990, Frankfurt/Main, Peter Lang, 1992.

Wysocki, G., Die Geheime Staatspolizei im Land Braunschweig. Polizeirecht und Polizeipraxis im Nationalsozialismus, Frankfurt/Main, Campus Verlag, 1997.

Zehr, H., Crime and the Development of Modern Society. Patterns of Criminality in Nineteenth Century Germany and France, London, Croom Helm, 1976. 